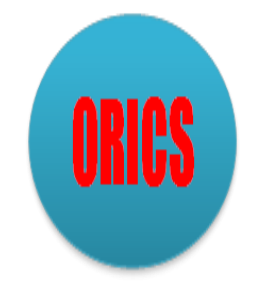

Available online at http://iorajournal.org/indx.php/orics

Operations Research: International Conference Series

Vol. 1, No. 1, pp. 1-12, 2020

\title{
Analysis of the Aggregate Heuristic Planning for Planning and Controlling the Amount of Production to Minimize Costs
}

\author{
Riana Magdalena \\ Department of Industrial Engineering, Faculty of Engineering, Atma Jaya Catholic University, Indonesia \\ Corresponding author: riana.magdalena@atmajaya.ac.id
}

\begin{abstract}
PT.XYZ is one of the companies engaged in the automotive manufacturing industy, where it produces spare parts for cars, motorcycles and trucks. Along with marketing and producing the products, PT.XYZ continues to implement customer satisfaction and the quality of spare parts produced. The company must anticipate the possibility of production capacity limitations; this must be done as well as possible at the minimum cost. For that, the aggregate heuristic planning is proposed for planning the establishment of a level for production capacity to meet the level of demand obtained from orders with the aim of minimizing total production costs. Aggregate Planning is a process of determining the level of overall production capacity to meet the level of demand obtained from forecasting and order with the aim of minimizing the total cost of production. In this study, three heuristic methods were tried, namely labor control method, subcontracting mixed method, and overtime mixed methods. Based on the results of the study it is known that the subcontracting mixed method is the best method with total aggregate cost of IDR 3,080,689,770, then the labor control method with a total of aggregate cost of IDR 3,080,798,198 and the overtime mixed method, with a total aggregate cost of IDR 3,081,815,315.
\end{abstract}

Keywords: Aggregate planning, heuristic method, labor control, subcontracting mixed method

\section{Introduction}

PT.XYZ is a company engaged in the field of automotive manufacturing, where the company produces automotive spare parts that will be marketed to automotive companies such as Astra Daihatsu Motor, Hino Motors Manufacturing Indonesia, And Motorcycles, Mekar Armada Jaya and many more. PT.XYZ uses a make to order production system, where companies will conduct qualitative forecasting every month based on the experience of the Production Planning and Inventory Control (PPIC) to determine the amount of raw material requirements.

The core is increasing if it handles the requests of the 19 permanent customers. Of course the constraints that will become the company's main target is increasing productivity in anticipation of increasing consumer demand through limited production capacity. Therefore, in anticipating the possibility of inadequate production capacity, planning of capacity requirements must be carried out as well as possible at the minimum cost. 
Problems with production capacity being faced by PT. XYZ is a problem that can have a detrimental effect on the company. Therefore there is a need for further studies using production capacity level planning using forecast history demand data to estimate the total costs to be incurred in the future, so the company can minimize the total production costs that must be used every month.

In this study used aggregate planning method in making the framework of the planning process of determining production capacity or can be said as a level of output as a whole, in order to meet the level of demand obtained from orders with the aim of minimizing total production costs. This plan is proposed for the production management section as an effort to determine the best way to meet demand by adjusting production levels, labor requirements, inventory, overtime, sub-contracts and all companycontrolled variables.

\section{Materials and Methods}

\subsection{Materials}

The following is the historical data of the request of PT. XYZ for 6 periods of 2018:

Table 1. Demand PT.XYZ in 2018

\begin{tabular}{llc}
\hline No. & Period & \multicolumn{1}{c}{ Kemand/Unit/ } \\
\hline 1 & July & $6,810,684$ \\
\hline 2 & August & $4,510,015$ \\
\hline 3 & September & $4,272,576$ \\
\hline 4 & October & $5,107,480$ \\
\hline 5 & November & $3,851,119$ \\
\hline 6 & December & $6,703,342$ \\
\hline Total & & $31,255,216$ \\
\hline
\end{tabular}

The following are data on company provisions and policies and assumptions used in processing data:

- $\quad$ Number of workers at PT. XYZ as many as 225 people.

- The capacity of the factory is limited by labor-hour which is available 24 hours per day and the number of days per week as much: 5 working days.

- $\quad$ Two shifts $=8$ hours are operated in one day.

- $\quad$ Expected time efficiency: $90 \%$.

- Appointment of new workers with a maximum of $7.3 \%$ from the initial workforce. With a maximum number of workforce of 10 people/ period.

- If there is an excess of labor, the maximum dismissal is 2 people/shift/period.

- While the holding cost (holding cost) is IDR $1,500 / \mathrm{kg} /$ period.

- $\quad$ Labor costs of IDR 2,276,990/ person/period (based on Banten Employee Minimum Wage).

- $\quad$ Based on the decision of the company's HR manager, the costs incurred for hiring or recruiting workers are at $85 \%$ of regular wage.

- $\quad$ Overtime costs per day IDR 26,323/day. Per person IDR 13,161/day

\subsection{Methods}

This research combines historical and descriptive methods. PT.XYZ in dealing with insufficient production capacity and the company gets the optimal profit in each production. To anticipate the possibility of inadequate 
production capacity, planning capacity requirements must be carried out as well as possible at the minimum cost. So that there is no limited production capacity and the company gets the optimal profit in doing each production.

According to Bedworth, aggregate planning is "Planning made to determine the demand for all elements of production and the amount of labor needed" (Bedworth \& Bailay, 1987; Kondoj et al, 2016). Aggregate planning is part of a larger production planning system, so that an understanding of the relationship between plans and several internal and external factors is useful. In a manufacturing company environment, the main production schedule produced provides input for the Material Requirement Planning (MRP) system which prioritizes the acquisition or production of the required components (Gaither \& Frazier, 1999; Heizer \& Render, 1993; Husien \& Abduljabbar, 2018). Detailed work schedules for labor and prioritized scheduling for products are produced as the final stages of the production planning system (Monks, 1982; Slack et al, 2003; Tesic et al, 2016).

The interesting thing in considering time is that Aggregate Planning is a medium-term production plan. The planning horizon usually ranges from 1 to 24 months or can vary from 1 to 3 years. Horizon depends on product characteristics and production period. The purpose of production planning is to arrange a production plan for alternatives that are available with the minimum cost of the entire product. Aggregate planning means combining appropriate resources into more general and comprehensive terms. With the demand forecast, as well as facility capacity, the supply of labor quantities and production inputs that are interrelated, the planner must choose the level of output for the facility for the next three to eighteen months. The probability to realize and apply to the real problem, trial and error method planning, by looking at the picture of cumulative demand and the average cumulative demand.

The following are five stages in the heuristic method of making methods (Heizer, 2006; Ridha, 2015):

1) Determine requests for each period

2) Determine what capacity at regular times, overtime, and Sub-contract actions for each period.

3) Determine labor costs, costs of hiring and dismissal of labor, and costs of adding inventory

4) Consideration of company policies that can be applied to workers and inventory levels.

5) Develop alternative plans and observe the total costs.

Forecasting is art and science to predict future events (Heizer, 1993). Forecasting is used to estimate conditions that can change so that planning can be done to meet future conditions. Business planning, profitability targets, and market expansion require a forecasting process. Forecasting is usually consideredseveral things, including: items to be predicted, for example products, product groups, or assemblies; forecasting techniques (qualitative or quantitative models); unit size (rupiah, unit, weight); time interval (week, month, quarter); forecasting horizon (what time interval is entered); forecasting component (level, trend, seasonal, cycle and random); forecasting accuracy (error measurement); exception report, special situation; and revisions to the parameters of the forecasting model.

Forecasting methods with time series (extrapolation or periodic series) use a history of past requests to see trend and seasonality for make predictions for the future (Buffa et al, 1996). The trend in question is the tendency of data while seasonality in question is a pattern of data history. The goal of this time series method is to identify historical data patterns and extrapolate these patterns for the future.

The introduction is done with the aim of getting to know the current condition of the company so that it can be used as a basic frame of mind in later stages. At this stage it is used to find out the problems faced by the company and to obtain information that can be used in the stages of further research. Introduction is the initial stage in preparing a report, where at this stage the researcher conducts an interview, where the interview is conducted with the aim of knowing the general condition of the company as a whole, so that problems can be identified in the company. In addition, researchers will conduct a field study that aims to find out and examine the factors that cause inadequate production capacity and planning of capacity needs to be done as well as possible with minimum costs by the company, so that the problem can be overcome by PT.XYZ in dealing with insufficient production capacity and the company gets the optimal profit in each production. 


\section{Results and Discussion}

\subsection{Demand Forecasting}

First, the demand data 2018 is plotted into a time series plot graph, it aims to see trends and seasonal trends from historical data. Forecasting is carried out for the next 6 periods, based on the results of the forecasting, which will be used as a reference for the cost of production capacity. The following is the time series demand in the 2018 period.

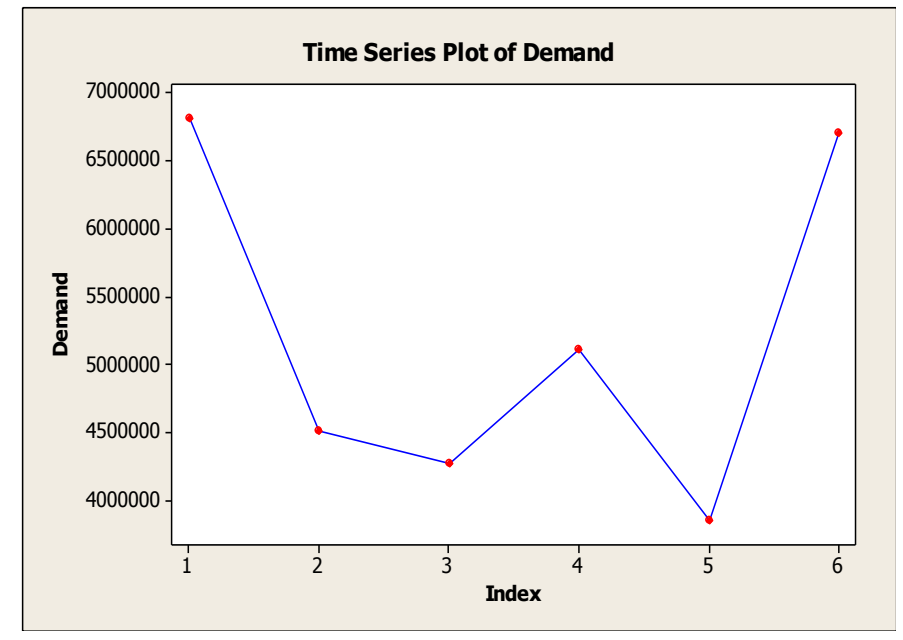

Figure 1. Time Series Plot Demand 2018

Time Series Plot Demand 2018, was determined using MINTAB 15 software. Based on the results of the demand plot time series 2018 shown in Figure 1, it can be seen that there is no trend and there is no seasonal pattern, so the best method used based on the literature review that has been sought is a Double Moving Average (DMA) (Kho \& Wong, 2007; Wang, 2008) and Single Exponential Smoothing (SES) (Nazim \& Afthanorhan, 2014; Risteski et al, 2004).

Following are the results for the forecast using MINITAB 15 software we can determine the Moving Average Plot for Demand shown in Figure 2. Forecasting results above, which must be considered, is the magnitude of error value listed where the error values listed are MAPE, MAD, MSD.

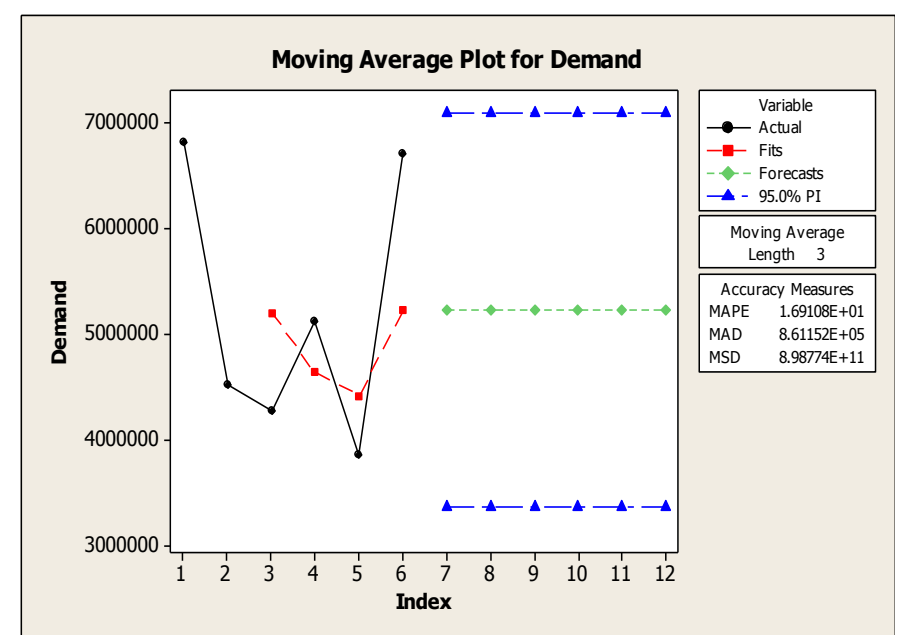

Figure 2. DMA Plot for Demand 
Figure 3 from the MINITAB 15 software, shows the results of the Double Moving Average (DMA) for the next 6 periods it is known that the error value indicator as follows:

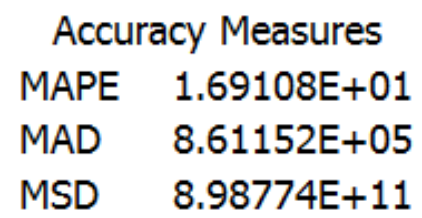

Figure 3. DMA Accuracy

Measures

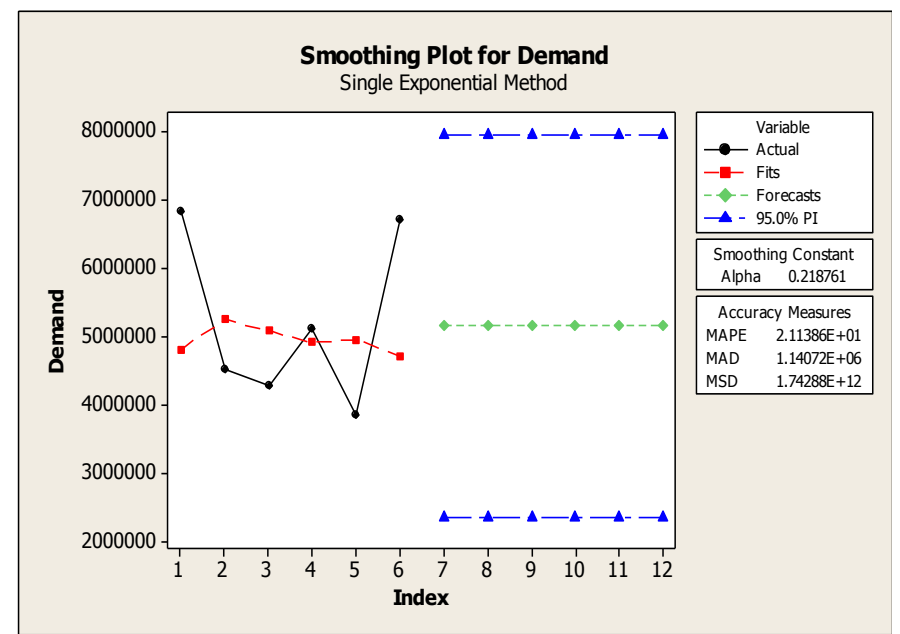

Figure 4.SES Smoothing Plot for Demand

Based on the results of the Single Exponential Smooting (SES) for the next 6 periods it is known that the error value indicator is as follows:

\begin{tabular}{lr}
\multicolumn{2}{c}{ Accuracy Measures } \\
MAPE & $2.11386 \mathrm{E}+01$ \\
MAD & $1.14072 \mathrm{E}+06$ \\
MSD & $1.74288 \mathrm{E}+12$
\end{tabular}

Figure 5. SES Accuracy Measures

Figure 4 shows the SES smoothing plot for demand. Forecasting results above, which must be considered, is the magnitude of error value listed where the error values listed are MAPE, MAD, MSD. The accuracy measures of SES is shown in Figure 5.

The following is a recapitulation table to compare the error value indicators of each method that has been done: 
Table 2. Error value recapitulation

\begin{tabular}{ccc}
\hline PARAMETER & DMA & SES \\
\hline MAPE & $1.69 \mathrm{E}+01$ & $2.11 \mathrm{E}+05$ \\
\hline MAD & $8.61 \mathrm{E}+05$ & $1.14 \mathrm{E}+06$ \\
\hline MSD & $8.99 \mathrm{E}+11$ & $1.74 \mathrm{E}+12$ \\
\hline
\end{tabular}

From the comparison of the error value indicator shown in Table 2, it can be seen that the DMA (Double Moving Average) has the smallest error value both from MAPE, MAD, and MSD, so the forecasting result used is a Double Moving Average. Data in Table 3 below is a request recapitulation table obtained from the MINITAB 15 software according to the chosen forecasting method. For the period, it starts with period January - June 2019.

Table 3. Forecast for January - June 2019 based on the results of 2018

\begin{tabular}{lll}
\hline No. & Period & Forecast \\
\hline 1 & January & $5,220,647$ \\
\hline 2 & February & $5,220,647$ \\
\hline 3 & March & $5,220,647$ \\
\hline 4 & April & $5,220,647$ \\
\hline 5 & May & $5,220,647$ \\
\hline 6 & June & $5,220,647$ \\
\hline \multirow{2}{*}{ Total } & & $31,323,88$ \\
\hline
\end{tabular}

\subsection{Heuristic Method of Aggregate Planning}

\subsubsection{Labor Control Method}

In this method, the production rate set is in accordance with the existing demand, and production shortages are overcome by the addition of labor, if there is an excess of production, a reduction in labor will be carried out, where the production plan with labor control can be see in Table 4 . It can be concluded that the company does not need to issue subcontracting costs. This occurs because the company's production capacity is equal to the number of demand forecasts, which results in cost savings by companies and companies do not need to delegate orders to other companies so that production needs can be fulfilled by the company.

Table 4. Recapitulation of Labor Control Method

\begin{tabular}{|c|c|c|c|c|c|c|c|}
\hline No & Period & $\begin{array}{c}\text { Demand } \\
(\mathrm{Kg})\end{array}$ & Hiring & Firing & Labor & Labor Cost & Total Cost \\
\hline 1 & Jan-19 & $5,220,647$ & 0 & IDR $108,428.10$ & 225 & IDR 513,448,295.06 & IDR $513,556,723.15$ \\
\hline 2 & Feb-19 & $5,220,647$ & 0 & 0 & 225 & IDR 513,448,295.06 & IDR 513,556,723.15 \\
\hline 3 & Mar-19 & $5,220,647$ & 0 & 0 & 225 & IDR 513,448,295.06 & IDR 513,556,723.15 \\
\hline 4 & Apr-19 & $5,220,647$ & 0 & 0 & 225 & IDR 513,448,295.06 & IDR 513,556,723.15 \\
\hline 5 & Mei-19 & $5,220,647$ & 0 & 0 & 225 & IDR 513,448,295.06 & IDR 513,556,723.15 \\
\hline 6 & Jul-19 & $5,220,647$ & 0 & 0 & 225 & IDR 513,448,295.06 & IDR 513,556,723.15 \\
\hline
\end{tabular}


Table 5. Recapitulation Subcontract Method

\begin{tabular}{ccccccccc}
\hline No & Period & $\begin{array}{c}\text { Demand } \\
(\mathbf{K g})\end{array}$ & $\begin{array}{c}\text { Production } \\
\text { Level }\end{array}$ & Subcontract & $\begin{array}{c}\text { Subcontract Cost } \\
\text { (IDR) }\end{array}$ & Labor & $\begin{array}{c}\text { Labor Cost } \\
\text { (IDR) }\end{array}$ & $\begin{array}{c}\text { Total Cost } \\
\text { (IDR) }\end{array}$ \\
\hline 1 & Jan-19 & $5,220,647$ & $5,220,647$ & 0 & 0,00 & 225 & $513,556,723.15$ & $513.448 .295,06$ \\
\hline 2 & Feb-19 & $5,220,647$ & $5,220,647$ & 0 & 0,00 & 225 & $513,556,723.15$ & $513.448 .295,06$ \\
\hline 3 & Mar-19 & $5,220,647$ & $5,220,647$ & 0 & 0,00 & 225 & $513,556,723.15$ & $513.448 .295,06$ \\
\hline 4 & Apr-19 & $5,220,647$ & $5,220,647$ & 0 & 0,00 & 225 & $5513,556,723.15$ & $513.448 .295,06$ \\
\hline 5 & Mei-19 & $5,220,647$ & $5,220,647$ & 0 & 0,00 & 225 & $513,556,723.15$ & $513.448 .295,06$ \\
\hline 6 & \multirow{2}{*}{ Jul-19 } & $5,220,647$ & $5,220,647$ & 0 & 0,00 & 225 & $\begin{array}{c}513,556,723 . \\
15\end{array}$ & $513.448 .295,06$ \\
\hline \multicolumn{7}{c}{ TOTAL COST } \\
\hline
\end{tabular}

Because using the moving average forecasting method as specified, the forecast results are the same for the six periods. So, from the calculation above the firing costs in January amounted to IDR $108,428.10$ and total labor control in January was IDR 513,556,723.15. Furthermore, if the cost of controlling labor is totaled for six periods, then the cost to be incurred by the company is IDR $3,080,798,198.45$.

\subsubsection{Subcontract Control Method}

In the subcontract control method, the company delegate's orders that cannot be fulfilled to other companies with the assumption that the cost per $\mathrm{kg}$ is IDR 2,000, and the monthly production rate is taken from the smallest demand, then the calculation for the subcontracting control method. The subcontract control method is shown in Table 5. The total cost of subcontracting per period that must be spent by the company is IDR 513,448,295.06 and the total cost of subcontracting from the six periods is IDR 3,080,689,770.36.

\subsubsection{Mixed Method With Overtime}

Overtime or overtime needs to be planned well so that it does not harm the company, this is because overtime costs are definitely higher than the usual work time costs. Mixed methods with overtime are shown as follows:

- The level of monthly production is regulated based on the smallest demand, but because demand is equal, so the demand used is the same as demand in the six periods $=5,220,647 \mathrm{units} / \mathrm{kg}$.

- $\quad$ Overtimecapacit $y=$ worker $\max \times$ sunday $\times$ worker output/day $=225 \times 4 \times 1102=992,229$.

- Overtime is permitted for the amount of work hours of a person / period with overtime costs per day $=$ IDR 80,000.00, -

- Hourly overtime wages Rp3,333.33/hour.

- $\quad$ Lack of regular time $=$ Regular time - Demand $=5,220,647-5,220,647=0$

- $\quad$ OT Fee $=$ Lack of RT $\times$ OT Fee $=0 \times 24,19=$ IDR0.00.

- $\quad$ Labor $=$ Production level: labor output $/$ month $=5,220,647: 23.152=255$

- $\quad$ TK Fee $=$ Labor $x$ worker salary / month $=255 \times 2,276,990=$ IDR 513,448,295.06

- $\quad$ Firing costs $=($ Demand - production average/ month $) x$ firing cost $/ \mathrm{kg}=(5,220,647-5,209,202.67) \mathrm{x}$ IDR. $98.00=$ IDR $1,125,545$

- The total cost that must be incurred by the company if using the overtime mixture method is equal = IDR 1,125,545 + IDR 3,080,689,770.36 = IDR 3,081,815,315.42

From the results of the overtime mixture calculation the results of overtime per period are IDR $513,448,295.06$. The results are the same as the results of the calculation of sub-contract costs. Due to the 
result of a regular time shortage minus demand equal to 0 , this is due to production capacity equal to current demand. What distinguishes this method is that when the total costs for the six periods are summed up with the firing costs, the results are obtained by a total cost of IDR 3,081,815,315.42.

\subsection{Comparison Aggregate Planning Heuristic Method}

From Table 6 below it can be concluded that the method that is closest to minimizing total production costs is to use subcontracting control methods where the smallest result is the cost of the calculation of control by subcontracting.

Table 6. Comparison Aggregate Planning Heuristic Method

\begin{tabular}{ccc}
\hline Method & Total Cost & Rank \\
\hline Labor Control & IDR 3.080.798.198 & 2 \\
\hline Subcontract Control & IDR 3.080.689.770 & 1 \\
\hline Mixed Overtime & IDR 3.081.815.315 & 3 \\
\hline
\end{tabular}

\subsection{Analysis and Evaluation}

PT. XYZ is a manufacturing company that manufactures spare parts. The production system owned by this company is make to order, consumers make contracts to place orders every month. So that ordinary companies conduct quantitative forecasting based on the experience of the PPIC, forecasting is done by looking at the quantity of orders in the previous month then the PPIC will guess the forecast that will be used for the next three months. With high market demand, the company must also increase its production capacity.

Related to this, the operations management must also coordinate with the PPIC department for production planning, so that later the production capacity is unlimited or excessive. For this reason, the calculation of the total production costs for all related variables is used, which can be a factor of expenditure by the company.

At present, PT. XYZ has implemented the Loading vs. Capacity calculation, where the method can calculate the labor and machine needs that must be used by the company and also the existing production capacity needs, related to this method only calculates the needs of workers, production fulfillment demand capacity and only machines, but do not take into account the total production costs incurred by the company each period. Therefore, companies need to apply control methods to control the total cost of all existing factors such as using aggregate planning methods by taking into account labor control, subcontracting and mixed methods with overtime.

There needs to be a policy of controlling production capacity by operations management at PT.XYZ, to be able to walk and according to the plan of the company. So that the limited production capacity can be fulfilled and carried out as well as possible at the minimum cost. By doing the planning, the company will not experience limitations in production capacity and the company will get optimal benefits in each production. In this study the author took the theme of aggregate planning, in the framework of planning the process of determining production capacity as a whole, in order to meet the level of demand obtained from orders in order to minimize the total production costs of making spare parts.

This research is quantitative by using a heuristic approach by comparing three types of variations of aggregate planning, namely labor control, subcontracting control and overtime mixture control. The three types of variations use demand data for products, number of workers, number of hours in one working day, number of work days / months, labor wages, expected efficiency of production time, costs incurred due to inventory, costs incurred due to sub -contracts, overtime / day costs and the amount of productivity rate, the results of comparison can be used to calculate the costs incurred throughout the 
production plan which are described in the recapitulation table. Of the various costs, you can find out the most minimum costs that can be incurred.

In setting the forecast for the next six periods, the Minitab 15 software is used, the reference being the result of the time series plot. By knowing the trends and seasonal of the plot, the results of time series plot forecasting can be used as the next step to find out what methods are suitable for the demand forecasting. After seeing the results of the forecast is the trend no and seasonal no (random) which means that the historical data is random or the data does not rise or fall.

There are three indicators of error values shown in Figure 3 and Figure 5, namely MAD, MSE, and MAPE. MAD is the average absolute error during a certain period, while MSE is the average square of all forecasting errors in each period, while MAPE states the percentage of error forecasting results. Based on the three indicators shown in Table 2 which shows the Error Value Recapitulation, the DMA (Double moving average) has the smallest MAPE, MAD, and MAPE error indicators so that the output forecasting method chosen is used as forecasting company demand in the 2019 period.

Forecasting all months is the same, namely 5,220,647 units / $\mathrm{kg}$ in the period January - June 2019 shown in Table 3. This is because the pattern of random history requests so that the double moving average method performs forecasting by looking for the average value so that the forecasting output of all periods is the same.

Aggregate Planning is a process of quantity planning and setting the output time for the medium term, which is around 3 months to 1 year. This Aggregate Planning provides an overview to management regarding the need for production variables such as material inventories, labor and other resources so that operational costs can be controlled to a minimum. The description of the requirement must be able to present the quantity and time needed so that the production process can run as planned. The heuristic method is used in this study because this method is the most real planning method for probabilityrealized and applied to real problems, planning trial and error methods, by looking at the picture of cumulative demand and the average cumulative demand.

For labor control methods, because using the moving average forecasting method as specified, the forecast results are the same for the six periods. The results are shown in Table 4. So, it has an impact on reducing employees in the first month only (January) because of the difference in demand in the following months. So, from the calculation above the firing costs in January amounted to IDR. $108,428.10$ and total labor control in January was IDR. 513,556,723.15. Furthermore, if the cost of controlling labor is totaled for six periods, then the cost to be incurred by the company is IDR. $3,080,798,198.45$.

For subcontracting control methods shown in Table 5, it can be concluded that companies do not need to spend subcontracting costs. This occurs because the company's production capacity is equal to the number of demand forecasts, which results in cost savings by companies and companies do not need to delegate orders to other companies so that production needs can be fulfilled by the company. The total cost of subcontracting per period that the company must spend is IDR. 513,448,295.06 and the total cost of subcontracting from the six periods is IDR. 3,080,689,770.36.

The last is a mixed method with overtime. From the results of the calculation of the overtime mix ture the results of overtime per period are IDR 513,448,295.06. The results are the same as the results of the calculation of sub-contract costs. Due to the result of a regular time shortage minus demand equal to 0 , this is due to production capacity equal to current demand. What distinguishes this method is that when the total costs for the six periods are summed up with the firing costs, the results are obtained by a total cost of IDR 3,081,815,315.42.

Forecasting is used by companies to determine the forecasting process or production capacity in each period. The company still uses quantitative forecasting based on quantitative nature, but still depends on the level of education and one's experience in making the forecast.

The method used by the company is Loading Vs Capacity, where the method only calculates the number of workers needed, production capacity to consumer demand, and the machine to be used. The method was created by the company itself in knowing the level of engine efficiency that must be used, labor needed, time overtime of workers on production capacity, and production capacity based on consumer demand. This is not effective because the calculation with Loading Vs Capacity method does 
not cover all related variables such as the use of aggregate planning method, where the three variation methods use data on product demand, number of workers, number of hours in one work day, number of work days / month, labor wages, expected efficiency of production time, costs incurred due to inventory, costs incurred due to sub-contracts, daily overtime costs and amount of productivity rate, the results of comparison can be used to calculate costs incurred during production planning.

\section{Conclussion}

Based on the results of the research, the following conclusions are drawn: PT.XYZ is currently using the Loading Vs. Capacity method in determining the number of workers, machines used, production needs, and overtime for operators. Based on the results of interviews, using the Loading Vs. Capacity method, the average total cost to be incurred by the company is IDR 727,340,560.30 every period.

The results of the most minimal heuristic calculation method for total production costs in the next 6 months are subcontract control methods. The total cost for the six periods with the sub-contract control method is IDR $3,080,689,770$. The minimum total production cost generated in one period using a subcontracting calculation is IDR 513,448,295.06. The results of the research that has been done, the suggestions that can be given to PT. XYZ in forecasting it is good to use quantitative methods that are more appropriate in carrying out forecasting. The application of aggregate planning methods in the company in planning meets the level of demand and minimizes the total cost of production so as to reduce the total cost of inventory.

\section{References}

Bedworth, D., \& Bailey, J. (1987). Integrated Production Control Systems. Canada: John Wiley \& Sons.

Buffa, Elwood, S., \& Sharin, R. (1996). Manajemen Operasi \& Produksi Modern. Jakarta: Binarupa Aksara.

Gaither, N., \& Frazier, G. (1999). Production and Operations Management. South-Western Pub.

Heizer, J., \& Render, B. (1993). Production and Operations Management: Strategies and Tactics. New Jersey: Prentice Hall.

Heizer, R. (2006). Operations Management (Manajemen Operasi). Jakarta: Salemba Empat.

Husien, W. A., \& Abduljabbarm W. K. (2018). Using the Successful Implementation Road of MRP to Developing Iraqi Manufacturing Industries. Asian Journal of Information Technology, 17(4), 80-90.

Kondoj, M. A. S., Langi, H. S., \& Kasenda, S. R. (2016). Model Productivity in UKM Coconut Oil based on Information Technology in North Sulawesi. International Journal of Computer Application, 156(9), 10-13.

Khoo, M. B. C., \& Wong, V.H. (2007). A Double Moving Average Control Chart. Communications in Statistics Simulation and Computation, 37(8), 1696-1708.

Monks, J, G. (1982). Operations Management, 2nd Edition. USA: Mc Graw Hill.

Nazim, A., \& Afthanorhan, A. (2014). A Comparison Between Single Exponential Smoothing (SES), Double Exponential Smoothing (DES), Holt's (Brown) and Adaptive Response Rate Exponential Smoothing (ARRES) Techniques in Forecasting Malaysia Population. Global Journal of Mathematics Analysis, 2(4), 276-280.

Ridha, M. B. (2015). The Role of Heuristic Methods as a Decision-Making Tools in Aggregate Production Planning. International Journal of Business Administration, 6(2), 68-76. 
Risteski, D., Kulakov, A., \& Davcev, D. (2004). Single Exponential Smoothing Method and Neural Network in One Method For Time Series Prediction. Proceedings of the 2004 IEEE Conference on Cybernetics and Intelligent Systems, Singapore, 1-3 December 2004, 741-745.

Slack, N., Chambers, S., \& Johnston, R. (2003). Operations Management, 4th Edition. Canada: Pearson Education.

Tesic, Z., Stevanov, B., Jovanovic, V., Tomic, M., \& Kafol, C. (2016). Period Batch Control - A Production Planning System Applied to Virtual Manufacturing Cells. International Journal of Simulation Modelling, 15(2), 288-301.

Wang, C. (2008). Quantitative Analysis on the Bullwhip Effect in a Supply Chain Using Double Moving Average and Double Exponential Smoothing Forecasts. 2008 International Symposiums on Information Processing, Moscow, 114-118. 